\title{
Success Factors of Small and Medium Enterprises in the Malaysian Furniture Industry: Discerning the Growth of Entrepreneurs
}

\author{
Jegatheswaran Ratnasingam, ${ }^{\mathrm{a}, *}$ Hazirah Ab Latib, ${ }^{\mathrm{a}}$ Manohar Mariapan, ${ }^{\mathrm{a}}$ \\ Kamaruzaman Othman, ${ }^{\mathrm{a}, \mathrm{b}}$ Mohd Afthar Amir, ${ }^{\mathrm{a}, \mathrm{b}}$ and Lim Choon Liat ${ }^{\mathrm{a}}$
}

Entrepreneurs and small and medium enterprises are the foundation of the Malaysian furniture industry. Yet, in a multi-ethnic society such as Malaysia, the success factors of entrepreneurs and small and medium enterprises (SMEs) in the furniture industry have not been studied. Therefore, this study evaluated the success factors of entrepreneurs of the Malay and Chinese ethnic groups in the furniture industry and discerned the growth trajectory of young entrepreneurs from wood science and technology programs in the furniture industry. A questionnaire-based survey was used with the assistance of relevant trade associations and universities. The results were statistically analyzed to establish the significant differences between the two ethnic groups in their perceived success factors. The results revealed that Malay entrepreneurs pay more attention to political and socio-cultural factors to gain success, whereas Chinese entrepreneurs focus on enhancing their competitiveness to remain viable. Further, young graduates showed a reduced desire to pursue a career in the furniture industry, as they deem it not environmentally sustainable in addition to limited career growth. These results suggested that current entrepreneurship development programs may need to be revised, so as to assist in producing more resilient and successful entrepreneurs in the future in the furniture industry.

Keywords: Success Factors; SMEs; Furniture; Growth; Entrepreneurs; Young graduates

Contact information: a: Faculty of Forestry and Environment, Universiti Putra Malaysia, 43400 UPM, Serdang, Selangor, Malaysia; b: Malaysian Timber Industry Board, $10^{\text {th }}$ Floor, Menara PGRM, 8 Jalan Pudu Ulu, 55300 Kuala Lumpur, Malaysia; *Corresponding author: jswaran1965@ gmail.com

\section{INTRODUCTION}

Malaysia's growth from a low-income to an upper-middle income nation in just one generation is an economic success that has become the envy of many nations (World Bank 2021). Malaysia's notable achievements include the growth in gross national income (GNI) per capita, which grew at an average rate of 6.9\% per year from 1960 to 2017. In addition, under $1 \%$ of the population lives below the international extreme poverty line of 1.90 USD, international trade has grown approximately 300\%, Malaysia trades with $90 \%$ of countries, and life expectancy has steadily increased from 59 years in the 1960 s to 75 years in 2019. These successes can largely be attributed to the following development policies: (1) outward-oriented, labour-intensive growth, (2) investments in basic human capital to raise labour productivity, and (3) credible economic governance to maintain macroeconomic stability.

The wood-based industry is among the industrial sectors that have contributed to the country's economic growth. As an exporter of primary wood products, such as saw logs, sawn timber, and plywood since the early 1960s, Malaysia has grown into a multi- 
billion Ringgit Malaysia (RM) value-added wood product exporting nation. The major value-added wood products exported include furniture, builders' carpentry and joinery (BCJ), and mouldings, which constituted approximately $60 \%$ of the total wood product exports from the country in 2020 (MTIB 2020).

In the Malaysian wood-based industry, the furniture manufacturing industry is the star performer, as it constitutes $41 \%$ of total wood products exports, which provides the highest added value ratio of approximately 6.5 times. The growth of the Malaysian furniture industry has been studied extensively by Ratnasingam (2015), who concluded that the growth drivers of the industry include favorable industrial policy, competitive factor inputs, market demand, and a high level of entrepreneurial skills. Further, the prevailing low-entry barrier into the furniture industry coupled with the extensive cultural network among the industry players explains why the furniture industry had the highest number of startups among all manufacturing industries from 1990 to 2005 (Ratnasingam 2015). This period coincides with the $2^{\text {nd }}$ Industrial Master Plan (1996 to 2005), which prioritized the growth of the Malaysian furniture industry and encouraged the manufacture of higher value-added products. Therefore, it is no surprise that the Malaysian furniture industry grew rapidly and has emerged as the fastest growing sub-sector within the Malaysian wood-based industry (Fig. 1).
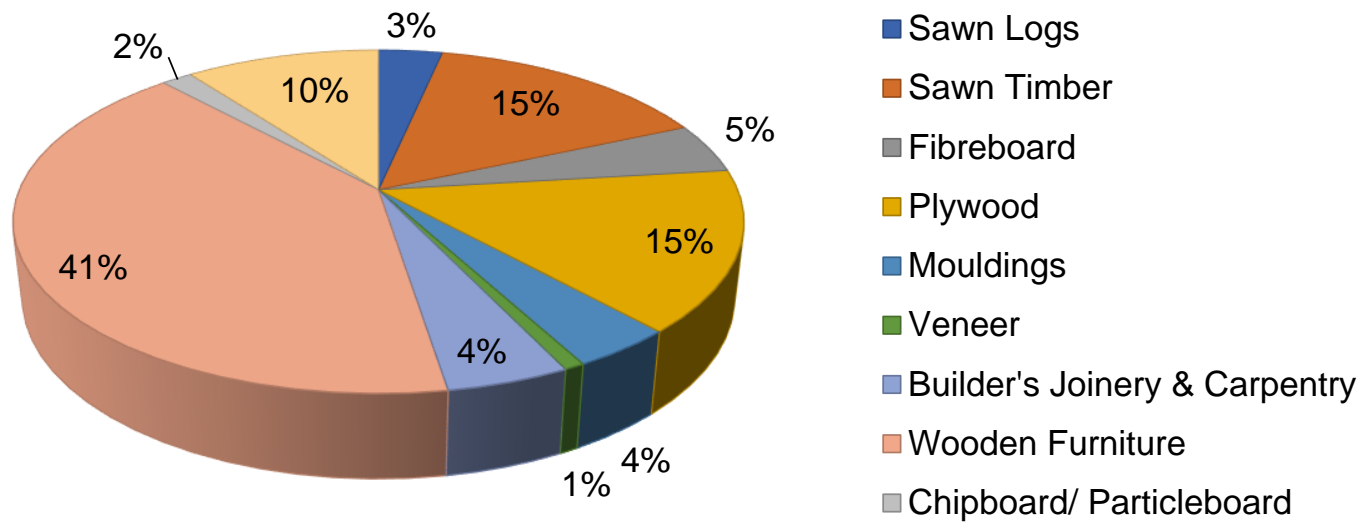

Fig. 1. Export of wood products (2019)

In 2019, Malaysia furniture exports constituted 11.38 billion RM of the total 22.1 billion RM of wood products exports. Wooden furniture made up $83 \%$ of total furniture exports, which clearly indicated the industry's reliance on wood resources (MTIB 2020). Further, as domestic demand for furniture has been fueled by a robust construction sector, Malaysia's domestic furniture market has been steadily growing and is valued at RM 8.9 billion. On a national level, the wood-based industry's contribution to the country's gross domestic product (GDP) was $1.5 \%$, which is small relative to other resource-based sectors, such as the rubber and oil palm industries. However, the strength of the wood-based industry, especially the furniture sector, lies in its high number of small and medium enterprises (SMEs) that develop new entrepreneurs and provide direct employment to approximately 105,000 people (MTIB 2020). Therefore, the socioeconomic importance of the furniture industry should not be understated, especially in terms of the employment opportunities it creates. 


\section{SMEs in the Furniture Industry}

In Malaysia's manufacturing industry, SMEs are defined as firms with annual sales that do not exceed RM 50 million or have less than 200 full-time employees on staff (SME Corp. 2020). Small and medium enterprises represent over $95 \%$ of the total business establishments, and they contribute over $40 \%$ of the total output, over $60 \%$ of total employment, and over $45 \%$ of the total value added since 2000 (BNM 2020). In recognizing the importance of SMEs, the government continues to be supportive of the development and expansion of SMEs, which has a strong impact on widening the economic divergence of the country's economy (BNM 2020).

The Malaysian business environment is unique due to the existence of multi-ethnic groups that operate and behave in unique ways that best suit them (Minai and Lucky 2011). Analysis of economic activities has shown that certain ethnic groups dominate certain types of business, but the disparity has declined due to affirmative government interventions (Gomez and Sarvanamuttu 2013). However, the Chinese ethnic group has a strong hold on the business sector, as they own $50 \%$ of equity of the construction sector, $74 \%$ of wholesale trade, $56 \%$ of retail trade, and 38\% of the manufacturing sector (BNM 2020). Although the Malay ethnic group, or the Bumiputera, make up approximately $62 \%$ of the total population and enjoy strong political, administrative, and government support through affirmative actions, their performance in many economic sectors remain lagging.

Since the implementation of the New Economic Policy (NEP) in 1971, government development programs have focused on achieving national unity in a multi-racial society through an integrated approach to eradicating poverty. One of the main strategic thrusts of the NEP is the development of Malay entrepreneurship as an objective to be accomplished by establishing the Commercial and Industrial Community (BCIC). The BCIC aims to increase the participation of Malay entrepreneurs in competitive and sustainable trade and industry activities at both domestic and international levels (BNM 2020).

The contributions of SMEs to the development of the furniture industry in Malaysia are important (Ratnasingam 2015). Because it is a traditional and labor-intensive industry, SMEs are the backbone of the furniture sector. The SMEs provide the needed flexibility in product design and volume production in the fashion sensitive global furniture market. According to Ratnasingam (2015), SMEs represent $85 \%$ of all registered furniture manufacturing enterprises in the country and constitute the most important element of industrial development.

According to the International Furniture Research Group (IFRG) (2018), approximately $94 \%$ of the existing furniture SMEs belong to the Chinese ethnic group, whereas the Malay ethnic group owns only 3\% of the SMEs in the furniture industry. However, the number of new SME startups in the furniture manufacturing industry has been declining for the last 2 decades (IFRG 2018), which suggests that the number of new entrants is limited, and entrepreneurs are reluctant to venture into this industry (Fig. 2). According to the IFRG (2018), the industry's production capacity has remained stagnant for the last several years, which supports the argument that new entrepreneurs are avoiding the industry. Ratnasingam and Teoh (2019) suggested that this trend could be attributed to the cut-throat competition within the industry, and relatively mature industries offer limited room for new entrepreneurs to gain market share unless they develop a completely new business model or product type. Consequently, this trend may also impact the development of young entrepreneurs, especially the Wood Science and Technology (WST) graduates who may be considering entrepreneurship within the furniture industry. 


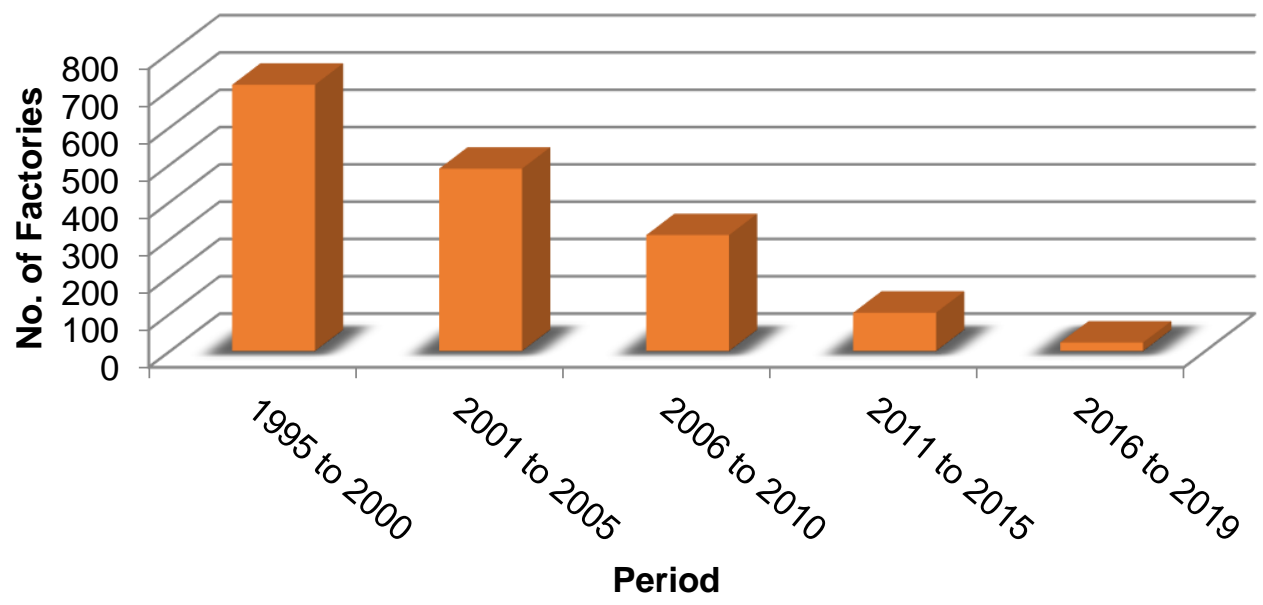

Fig. 2. New startups in the furniture industry in Malaysia

The factors that influence entrepreneur or SME success have attracted intense research interest over the last decade. The urgency of the question has increased since the onset of the COVID-19 pandemic, as approximately $37 \%$ of the total operating SMEs in the country reported notable reduction in business activity and require government assistance to remain afloat (SME Corp. 2020). Although many studies have examined the performance of entrepreneurs of a particular ethnic group (Gomez and Saravanamuttu 2013) and the success factors of SMEs in the manufacturing industry, comparative studies on the characteristics of two different ethnic groups in the furniture industry have yet to be published (Ratnasingam 2015). Such a study is particularly important, as it would highlight the strengths and weaknesses of each ethnic group and indicate what strategies and policy framework could facilitate the success of both ethnic groups and ensure their competitiveness and business growth.

\section{Entrepreneurship as a Potential Career Path for WST Graduates}

The interest of recent graduates in pursuing a university education in the field of WST has been extensively studied (Ratnasingam 2015, 2018). Throughout the world, declining enrollment in WST programs has been observed (Gardner et al. 2005; Armstrong et al. 2014), and it has resulted in the closure of programs, rebranding, and mergers with allied fields of study (Smith and Valverde 2019). Even in South East Asia, which has a large wood products industry, the interest of recent graduates in pursuing a degree in WST is declining, and many reasons have been cited for this negative impact. The main reasons include the lack of career growth opportunities in the predominantly family-owned wood products businesses, comparatively low wages, lack of technology application, poor working conditions, the availability of 'greener pastures' in other industries, and the limited opportunities for entrepreneurship in a matured industry (Ratnasingam et al. 2018).

Graduate entrepreneurship is being aggressively promoted by the government of Malaysia to overcome the challenges posed by the prevailing high graduate unemployment, which has been further accentuated by the COVID-19 pandemic (SME Corp. 2020). Since the launch of the scheme in early 2020, the uptake among unemployed graduates has been relatively slow, and this trend has been even more apparent among WST graduates. There seems to be a greater interest in the digital economy rather than traditional manufacturing industries (FMM 2021). Therefore, it is no surprise that WST graduates prefer to seek employment or become entrepreneurs in other economic sectors and avoid the wood 
products industry. A survey by the Malaysian Furniture Council in 2019 on graduates who had completed their WST program over the last 3 years found that only $11 \%$ of all woodrelated program graduates seek employment in the wood products industry, and a large proportion of them are employed in non-related sectors (Fig. 3). This is most likely attributable to the fact that the furniture industry thrives on incremental factor inputs, rather than productivity gains. Further, value-addition has been stagnating in the industry (Ratnasingam 2015; Ratnasingam et al. 2021). Thus, the extent of entrepreneurship opportunities in the furniture industry needs an in-depth examination to identify the main challenges faced by these potential young entrepreneurs. Therefore, a study was undertaken to determine the success factors of entrepreneurs from two ethnic groups in the furniture manufacturing industry. The second objective was to evaluate the challenges faced by young WST graduates in pursuing entrepreneurship as a career, which increases their employability within the industry. The outcomes of this study will have implications for entrepreneur development programs both within the industry and among young WST graduates.

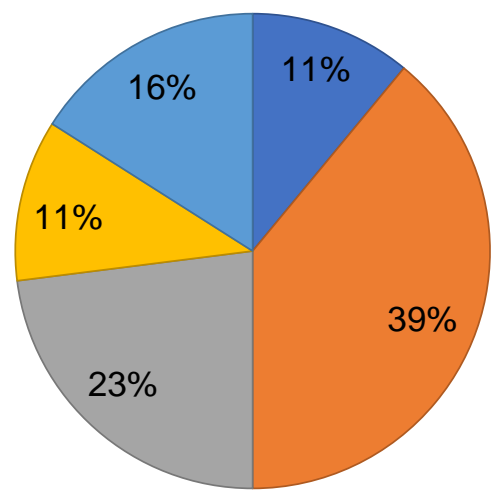

$\square$ Wood-related Industry

$\square$ Sales and Marketing

$\square$ Education

$\square$ Furniture Industry

$\square$ Others

Fig. 3. Career path of WST graduates

\section{METHODOLOGY}

Research on the success of SMEs is extensive (Simpson et al. 2012; Halabí and Lussier 2014), but Lampadarios et al. (2017) provided the most elaborate framework on entrepreneurship development and the related success factors. Their framework was developed from existing literature, which included entrepreneurship and SME specific studies and incorporated factors that contribute to all aspects of small business success (growth and non-growth) and failure. The framework draws upon influential studies and established models in the areas of SMEs and entrepreneurship (Rogoff et al. 2004; Simpson et al. 2012; Global Entrepreneurial Monitor 2021), which is then expanded to include the plethora of studies that were conducted in various industries and countries. The conceptual framework on the success factors of SMEs is shown in Table 1. This framework is in line with the PESTLE analysis framework, and it is comprised of political, economic, sociocultural, technological, legal and regulatory, ecological, and environmental factors.

To achieve the first objective of the study, a self-administered questionnaire-based survey of carefully selected entrepreneurs in the Malaysian furniture industry from both ethnic groups (i.e., Malay, and Chinese) was carried out. To select suitable respondents for this study, the Malaysian Furniture Council (MFC) and the Bumiputera Wood Products 
and Furniture Manufacturers Association (PEKA) provided assistance. Of 107 Malayowned and 217 Chinese-owned SMEs with comparable business operations, only 31 Malay-owned and 34 Chinese-owned SMEs consented to participate in this study. Further, all of the respondents have been in business between 10 to 15 years, and the respondents were mostly owners of the factories, or general managers at the factories. It must be noted that all the respondents were male aged between 46 to 58 years, while only one respondent was a female aged 39 years. Although the Chinese owned companies predominate the furniture manufacturing industry in Malaysia, efforts were made to ensure that diversity of respondents were achieved.

Table 1. Conceptual Framework on Drivers of Entrepreneurial Growth

\begin{tabular}{|c|c|c|}
\hline Entrepreneurial Factors & Enterprise Factors & Business Environment \\
\hline Age & Age and Size of Company & Political \\
Education Level & Business Networks \\
Entrepreneurial Orientation & Customer Relations Management \\
Gender & Financial Resources \\
Personality & Internationalization \\
Human Capital & Technological \\
Prior Work Experience and & Legal and Regulatory \\
Management Skills & Environmental \\
& Ecological \\
& Market and Product Development \\
Marketing & Strategic Planning & \\
\hline Source: Lampadarios et al. (2017) & & \\
\hline
\end{tabular}

Because the collection of data was qualitative in nature and based on predetermined themes (Table 1), the use of sophisticated methods of analysis was not deemed necessary, and this part of the study drew upon the basic principles of qualitative content analysis. This is a well-established, flexible, and straightforward qualitative data analysis method that represents a systematic and objective means of describing and quantifying phenomena (Schreier 2012; Finfgeld-Connett 2014). The questionnaire was designed after consultation with industry experts and the Small \& Medium Enterprise Corporation of Malaysia (SME Corp.), and it was pre-tested among a group of 15 existing industry workers to obtain their feedback and assess the ease of implementation. The comments and feedback received from the pre-testing were used to improve the questionnaire. The final version of the questionnaire was then mailed to the respondents who had agreed to participate in the study, and the completed questionnaires were returned 1 month later in a postage-paid and addressed envelope. The questionnaire aimed to capture the background of each SME and the factors deemed important for their success in the furniture industry. The success factors were evaluated based on their importance with a score of 1 (least important) to 5 (most important) for entrepreneurs from both ethnic groups. A third question in the questionnaire required the respondents to identify the three most important challenges faced by them in the Malaysian furniture industry. The data was extracted and collected from the responses to the questionnaire, collated under the pre-determined categories, reduced, summarized, and finally reported.

The second objective of the study was fulfilled through an online questionnairebased survey of final year students in WST programs throughout the country, which involved five universities, including Universiti Putra Malaysia, Universiti Teknologi MARA, Universiti Malaysia Kelantan, Universiti Tun Hussein Onn, and Universiti Malaysia Sarawak. The questionnaire was prepared using Google Forms, and the link to the questionnaire was shared with counterparts from the participating universities. The questionnaire was designed and modified with input from senior academics, industry 
experts, and alumni associations, and it was further refined after several consultations with the Federation of Malaysian Manufacturers (FMM), the SME Corp., and the Malaysian Furniture Council (MFC). A total of 149 final year students in WST programs and 28 students in post-graduate programs in the field of WST had responded after 3 months. The questionnaire had four questions, which were designed to capture the respondents' interest in venturing into the furniture industry and pursuing a career as an entrepreneur. The first question required the respondents to rank four factors (i.e., wage level, career growth opportunities, working conditions, and environmental sustainability) that impacted their decision to pursue a career in the furniture industry. The second question required the respondents to rate the relative importance of seven factors (i.e., industry maturity, lack of innovation, excessive competition, experience-focused rather than knowledge-focused, over dependence on contract workers, uncertain raw material supply, and lack of clear vision for the furniture industry) on a Likert scale of 1 (least important) to 5 (most important). This question aimed to capture the respondents' perception of the factors that affected the prevailing entrepreneurship opportunities within the industry. The third question required the respondents to rank the body of knowledge (i.e., process engineering, material science and technology, entrepreneurship skills, marketing, business skills, and computer and digital technologies, and industry 4.0 enabling technologies) that was perceived to be lacking in their present study programs to prepare them for a career in the furniture industry. The final question required the respondents to rate the effectiveness of entrepreneurship development in the universities in the context of the furniture business on a 5-point Likert scale.

The survey responses were recorded in a spreadsheet and imported into the SPSS version 10.1 statistical analysis software (IBM Corp., Armonk, NY, USA). The data were edited, processed, and analyzed using relative statistical tests, such as frequencies, descriptive statistics, crosstabs, and independence tests between all the variables using the $\chi^{2}$ criterion. These tests were conducted based on the questionnaire's content validity and credibility, which had Cronbach-alpha scores that ranged from 0.60 to 0.73 , as suggested previously by Mazzarol (2015).

\section{RESULTS AND DISCUSSION}

\section{Part I: Entrepreneur Success Factors}

In part 1 of the study, the entrepreneurial factors deemed necessary for success as an SME was markedly different between the two different ethnic groups (Table 2). The results from the survey suggested that Malay-owned SMEs paid the most attention to prior work experience and management skills, whereas Chinese-owned SMEs were more likely to focus on entrepreneurial orientation, followed by prior work experience and management skills. All other factors under this category were of similar importance to the two ethnic groups. Lampadarios $(2015 ; 2016)$ reported that entrepreneurial orientation and prior work experience and management skills were identified as the most important entrepreneurial success factors for SMEs in the manufacturing industry. An in-depth understanding of the workings of the industry, which is known as 'entrepreneurial orientation,' is an essential characteristic for successful entrepreneurs. This explains why the Chinese-owned SMEs are more competent in riding the economic cycles and remain resilient in tough times, whereas the Malay-owned SMEs generally lack the tenacity to ride out tough times (Gomez 1999; Gomez et al. 2004; Ann 2006; Gomez and Saravanamuttu 2013; Lampadarios 2017). 
Table 2. Comparison of Entrepreneurial Factors

\begin{tabular}{|c|c|c|}
\hline Factors & Malay-owned SMEs & Chinese-owned SMEs \\
\hline Age & 3.1 & 3.3 \\
\hline Education Level & 3.9 & 3.5 \\
\hline Entrepreneurial Orientation & 3.7 & 4.8 \\
\hline Gender & 3.8 & 3.9 \\
\hline Personality & 3.8 & 3.8 \\
\hline Prior Work Experience and Management \\
Skills
\end{tabular}

Table 3 shows the enterprise factors deemed important by the two ethnic groups. Both groups had similar perceptions of the important factors. The internationalization factor was a notable difference. The Malay-owned SMEs appeared to pay less attention to this point, as they have access to domestic government contracts with less stringent market requirements. Therefore, they prefer to operate within the domestic market, which is less competitive and has desirable lucrative government contracts (Gomez et al. 2004).

Table 3. Comparative Enterprise Factors

\begin{tabular}{|c|c|c|}
\hline Factors & Malay-owned SMEs & Chinese-owned SMEs \\
\hline Age and Size of Company & 3.5 & 3.7 \\
\hline Business Networks & 3.2 & 4.2 \\
\hline Financial Resources & 3.5 & 3.8 \\
\hline Internationalization & 2.9 & $\mathbf{4 . 6}$ \\
\hline Human Capital & 3.5 & 3.6 \\
\hline Market and Product Development & 3.7 & 3.9 \\
\hline Marketing & 3.3 & 3.7 \\
\hline Strategic Planning & 3.3 & 3.4 \\
\hline Note: 1 = least important; 5 = highly important & \\
\hline
\end{tabular}

In the category of business environment factors, the Malay-owned SMEs were more focused on political and socio-cultural factors, which they believed would boost their success chances. In contrast, the Chinese-owned SMEs were more focused on technological, legal and regulatory, and economic factors, which they believed were more crucial determinants of business success (Table 4). These results reflect the prevailing mindset among Malay-owned SMEs, as they have been provided with assistance and support from many agencies, such as the Malaysian Timber Industry Board (MTIB), the Peoples' Trust Council (MARA), and the SME Corp. to enable them to gain a competitive edge. Unfortunately, this 'rent-seeking' mindset has indeed stifled their competitiveness and made them more dependent on support, networking, and political patronage to gain success (Gomez 2002; Gomez and Saravanamuttu 2013). Many Malay-owned SMEs lacked the business acumen gained from operating in the open market, whereas the Chinese-owned SMEs appear to thrive in the open market. Therefore, the results of this study emphasized that successful entrepreneurship in the furniture industry should be built on competition rather than assisted-development programs. The success factors highlighted by the Chinse-owned SMEs were significantly different $(\mathrm{p}<0.01)$ between the two ethnic groups. Similar success factors were selected in other multi-ethnic entrepreneurial development studies (Benzing et al. 2009; Bonet et al. 2011; McLarty et al. 2012; Lampadarios et al. 2017). 
Table 4. Comparative Business Environment Factors

\begin{tabular}{|c|c|c|}
\hline Factors & Malay-owned & Chinese-owned SMEs \\
\hline Political & 4.4 & 3.1 \\
\hline Economic & 3.5 & $\mathbf{4 . 0}$ \\
\hline Socio-Cultural & 4.0 & 3.3 \\
\hline Technological & 3.8 & $\mathbf{4 . 6}$ \\
\hline Legal and Regulatory & 3.2 & $\mathbf{4 . 3}$ \\
\hline Environmental and Ecological & 3.1 & 3.4 \\
\hline Note: 1 = Least important; 5 = Highly important & \multicolumn{2}{|}{} \\
\hline
\end{tabular}

The main challenges faced by Malay-owned SMEs in the furniture industry were the lack of market and finances, whereas the Chinese-owned SMEs were faced with uncertain raw material supplies, an inconsistent legal and regulatory framework, and an insufficient workforce. Previous studies on the challenges faced by Malay-owned SMEs (Ratnasingam and Ioras 2003; Othman et al. 2005; Mamat and Ismail 2011; Braga 2017; Ratnasingam 2018; Osman et al. 2018a, 2018b, and 2019) have highlighted similar challenges. This indicates that entrepreneurial development programs with an emphasis on technical and management aspects may not be meeting the needs of Malay-owned SMEs, as improving entrepreneurial orientation, supply chains, and business networks appeared to be the most crucial needs for the Malay-owned SMEs in the furniture industry. The selected factors appear to be the major challenges faced by Malay-owned SMEs, and they continue to restrain their growth potential despite numerous the assistance and support schemes that have been employed (Awang et al. 2009; Ratnasingam 2018). In lieu of these revelations, cultural background and business environment play crucial roles in developing entrepreneurs in the Malaysian furniture industry, and the findings of this study supports this narrative. Further, it shows that the failure of Malay entrepreneurs to thrive in the highly competitive furniture business may be attributed to their lack of business acumen, lack of risk taking, and the weak business network. Further, such weaknesses cannot be addressed through technical and financial assistance, but should be handled through entrepreneurial development.

The Malaysian furniture industry is relatively mature, yet unlike other manufacturing industries, this industry is fragmented and is predominated by SMEs that are mostly family-owned. As a result, opportunities for mergers and acquisition (M\&A) activities are limited, and even the 18 public-list companies in the furniture industry, have divested their interests into other sectors such as construction, plantation, logistics, etc. (IFRG 2018). Therefore, the furniture industry needs new entrepreneurial talent, with a greater vision, to keep the industry vibrant and continue its growth path.

Cross-tabulation revealed that there was a marked difference in the success factors deemed important by the two ethnic groups. The statistically significant factors were entrepreneurial orientation, technology, internationalization, political, and legal and regulatory factors $(\mathrm{p}<0.001)$. Hence, Malay-owned SMEs were more politically and socio-culturally inclined, whereas Chinese-owned SMEs were focused on entrepreneurial orientation, technology, internationalization, and legal and regulatory factors.

\section{Part II: Entrepreneurship as a Career of Choice among WST Undergraduates}

In the second part of the study, the decision to pursue a career in the furniture industry was shown to be affected by the environmental sustainability and career growth opportunities. Figure 4 shows the relative importance of the four factors that impacted the decision of WST graduates to seek employment in the furniture industry. Figure 4 indicates 
that the young graduates deemed the furniture industry to be non-environmentally compliant, which leads to the 3D-stigma (i.e., dirty, difficult, and dangerous) associated with the industry. Unlike previously thought, young graduates were not solely driven by wages and working conditions in the furniture industry but rather appeared to be more environmentally conscious and seek higher job satisfaction (FMM 2021; Ratnasingam et al. 2021). Although, wood products and furniture are considered green products, the issue of the furniture industry perceived as being environmentally unsustainable is attributed to the negative publicity accorded to the wood industry as a whole, due to the increased activities of forest land conversion, illegal logging, emission of pollutants by industry, etc., which is quickly disseminated through the digital media (Ratnasingam et al. 2018) According to Noor et al. (2020), most of the forest offences reported continued to be 'sensationalized,' so that they continue to give a negative image to the overall forestry and wood products sector. Indirectly, such negative publicity leads to questioning of the effectiveness of the forest resource management in the country.

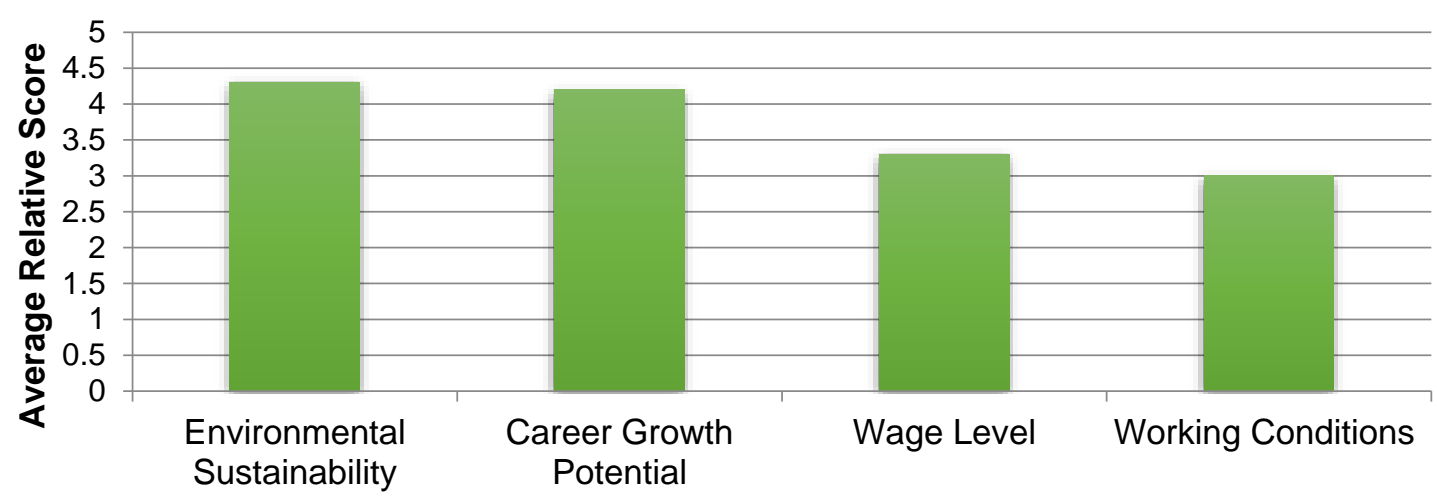

Factors

Fig. 4. Factors impacting the decision to pursue a career in the furniture industry

Table 5 shows that the three factors that limited the opportunities for entrepreneurship in the furniture industry were the lack of innovation, being experiencefocused rather than knowledge-focused, and the general lack of vision for the industry. This finding was in line with the stated objectives of the Industry 4.0 transformation being promoted by the government, whereby knowledge-workers should be highly sought after by the furniture industry (MITI 2018; Ratnasingam et al. 2019, 2020). The other factors were deemed less important, as they could be overcome through policy changes that could have immediate effects. Although the government has many programs to stimulate innovation and value-added manufacturing, the uptake within the furniture industry remains slow, which limits the opportunity for budding entrepreneurs.

Table 5. Entrepreneurship Limiting Factors

\begin{tabular}{|c|c|}
\hline Factors & Average Score \\
\hline Matured Industry & 3.2 \\
\hline Lack of Innovation & 4.4 \\
\hline Excessive Competition & 3.5 \\
\hline Experience-focused Rather Than Knowledge-focused & 4.3 \\
\hline Dependent on Contract Works & 3.4 \\
\hline Uncertain Raw Materials Supply & 3.3 \\
\hline Lack of Vision & $\mathbf{4 . 1}$ \\
\hline Note: 1 = Least important; 5 Highly important & \\
\hline
\end{tabular}

Ratnasingam et al. (2021). "Furniture success factors," BioResources 16(3), 5586-5600. 5595 
In evaluating the body of knowledge that is important for entrepreneurship development, process engineering, entrepreneurship skills, computer and digital technologies, and the key enabling technologies of Industry 4.0 were ranked highly (Fig. 5). This result was in line with the earlier study by Ratnasingam et al. (2018), who found that the dual-education system in Germany and other parts of Europe was an important reason for its industrial success, even in the woodworking sector. Education programs that take an engineering approach as opposed to the traditional materials science approach are more suitable for an industry that is poised to be transformed through the application of computer and digital technologies.

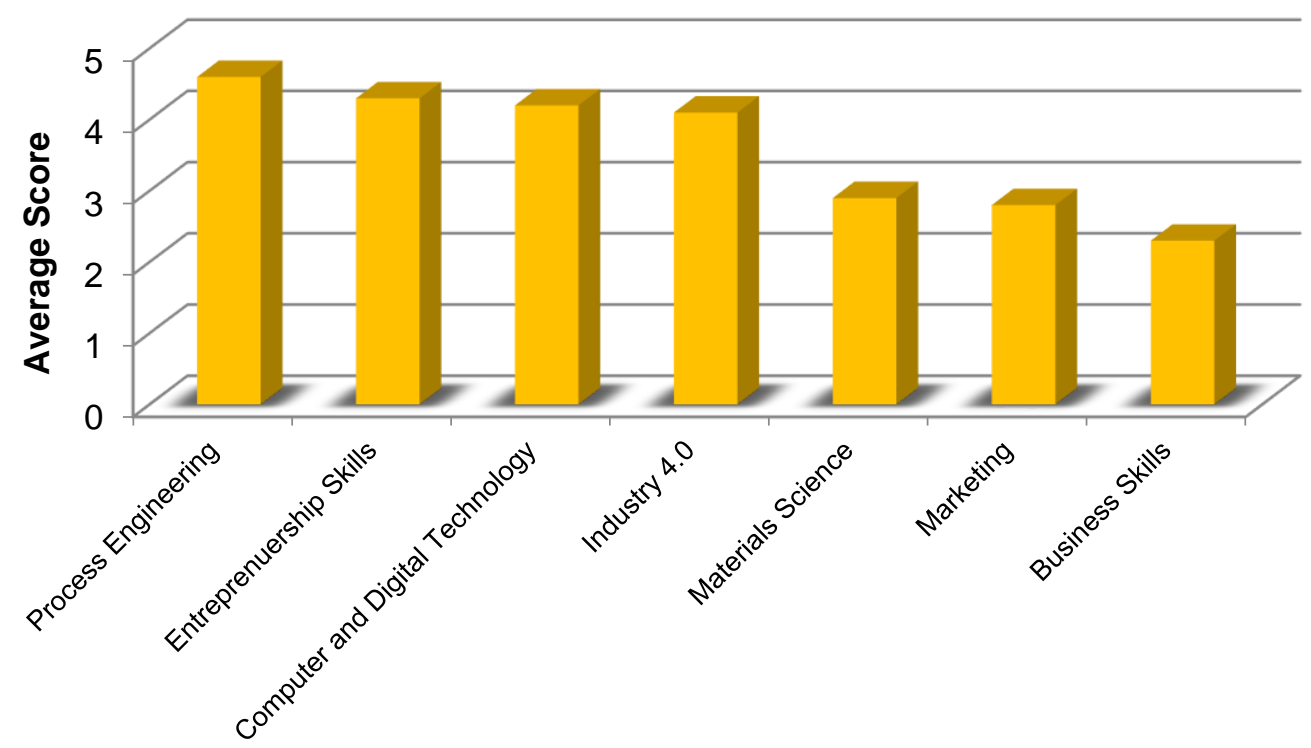

Factors

Fig. 5. Knowledge lacking in current WST programs

Finally, $100 \%$ of the respondents agreed that the entrepreneur development programs conducted at universities were ineffective for preparing them for the furniture industry, as they lacked an actual working environment, lacked mentorship, and most importantly lacked the structure necessary to develop entrepreneurs. This may explain the poor performance of participants who have attended entrepreneurship development programs at the training centers in Malaysia. Often, such participants move on to a career in another industry or sector despite having attended entrepreneurship training for 6 months to 12 months. Thus, entrepreneurial development must be based on a strategy that suits the furniture industry without sacrificing the trained human capital to ensure that the trained human capital is fully used (Lussier and Halabí 2010).

\section{IMPLICATIONS OF THE STUDY}

The findings of this study have far-reaching implications for entrepreneurship development in the Malaysian furniture industry, especially with regards to SMEs. In a multi-ethnic society such as Malaysia, successful entrepreneurs are developed when they operate in an open, competitive marketplace that requires them to have the necessary entrepreneurial orientation, market information, and technical and management skills. 
Without such conditions, entrepreneurial development cannot achieve the desired results, as the participants may lack the competitiveness to compete in the open market and will be forced to depend on political patronage and governmental support to remain afloat (Ratnasingam 2018). With such a varied perspective on the success factors that are important to entrepreneurs, the development of young entrepreneurs among WST graduates is also affected. Despite the low barrier of entry into the furniture industry, graduates of WST programs appear to avoid venturing into the furniture sector. Even for these entrepreneurs, the furniture industry is perceived to be environmentally unsustainable (possibly due to the negative publicity from forest clearance, illegal logging, and pollutant emitting activities) and have limited career growth opportunities. This result conflicted with the perception that the low wages offered and the prevailing poor working conditions in the furniture industry were deterring workers from seeking opportunities in the furniture industry (Ratnasingam et al. 2018). Further, the existing programs lack content that would give them an edge in the rapidly digitalizing industry. Thus, entrepreneur development among young graduates requires a strategy based on a new approach to impart the necessary knowledge and skills to improve the chances of successful entrepreneurship in the highly competitive furniture industry (Gomez 1999; Ratnasingam 2018).

\section{CONCLUSIONS}

1. The success factors of the entrepreneurs and SMEs in Malaysia's furniture industry were markedly different, which has a strong impact on its viability.

2. Malay-owned SMEs paid greater attention to political and socio-cultural factors, whereas Chinese-owned SMEs were more focused on building their core competitive strength on multiple perspectives on building international markets, entrepreneurial skills, and economic strength.

3. Young graduates of WST programs were reluctant to venture into the furniture industry because they perceived it to be environmentally unsustainable, with limited career growth opportunities, low wages, and poor working conditions.

4. To entice young graduates to seek entrepreneurial opportunities in the furniture industry, existing training programs must be revised and revamped to equip graduates with relevant knowledge and skills for the digital world.

\section{ACKNOWLEDGEMENTS}

The authors are grateful to the Malaysian Furniture Council (MFC) and the Bumiputera Wood Products and Furniture Manufacturers Association (PEKA) for their assistance with the implementation of the survey and data sharing. In addition, the authors thank Universiti Putra Malaysia (UPM) for funding this study through the PUTRA-Grant No. 9649900. 


\section{REFERENCES CITED}

Ann, W. S. (2006). The Business Secret of Chinese People, PTS Professional Publishing Sdn. Bhd, Kuala Lumpur, Malaysia.

Armstrong, J. P., Bustos, A. C., and Barnes, H. M. (2014). "Education in wood science and technology: An update," Wood and Fiber Science 46(1), 3-14.

Awang, A., Khalid, S. A., Yusof, A. A., Kassim, K. M., Ismail, M., Zain, R. S., and Madar, A. R. S. (2009). "Entrepreneurial orientation and performance relations of Malaysian Bumiputera SMEs: The impact of some perceived environmental factors," International Journal of Business and Management 4(9), 84-96. DOI: 10.5539/ijbm.v4n9p84

Bank Negara Malaysia (BNM) (2020). Performance of the Malaysian Economy (Economic Monitor No. 4.), Bank Negara Malaysia, Kuala Lumpur, Malaysia.

Benzing, C., Chu, H. M., and Kara, O. (2009). "Entrepreneurs in Turkey: A factor analysis of motivations, success factors, and problems," Journal of Small Business Management 47(1), 58-91. DOI: 10.1111/j.1540-627X.2008.00262.X

Bonet, F. P., Armengot, C. R., and Martín, M. A. G. (2011). "Entrepreneurial success and human resources," International Journal of Manpower 32(1), 68-80. DOI: $10.1108 / 01437721111121233$

Braga, M. F. (2017). "Ceasing copycat behaviour: Developing product-design identity through industry and handcraft interaction," Gestão \& Tecnologia de Projetos 12(2), 21-40. DOI: 10.11606/gtp.v12i2.110536

Federation of Malaysian Manufacturers (FMM) (2021). A Survey of Employment Opportunities in Malaysia in 2020, Federation of Malaysian Manufacturers, Petaling Jaya, Malaysia.

Finfgeld-Connett, D. (2014). "Use of content analysis to conduct knowledge-building and theory-generating qualitative systematic reviews," Qualitative Research 14(3), 341352. DOI: $10.1177 / 1468794113481790$

Gardner, D. J., Kurjatko, S., Kúdela, J., and Paule, L. (2005). "The status of wood science education programs," Wood and Fiber Science 37(2), 189-191.

Global Entrepreneurship Monitor (2021). Global Entrepreneurship Report 2019/2020, Global Entrepreneurship Research Association, London Business School, Regents Park, London, England.

Gomez, E. T., Loh, W. L., and Lee, K. H. (2004). "Development of Chinese entrepreneurs in the manufacturing sector," in: Chinese Business in Southeast Asia, Routledge-Curzon, London, England, pp. 62-84.

Gomez, E. T. (2002). Political Business in East Asia, Routledge Publication, London, England.

Gomez, E. T. (1999). Chinese Business in Malaysia: Accumulation, Accommodation and Ascendance, Curzon Press, Singapore.

Gomez, E. T., and Saravanamuttu, J. (2013). The New Economic Policy in MalaysiaAffirmative Action, Ethnic Inequalities and Social Justice, National University of Singapore Press, Lower Kent Ridge Road, Singapore.

Halabí, C. E., and Lussier, R. N. (2014). "A model for predicting small firm performance," Journal of Small Business and Enterprise Development 21(1), 4-25. DOI: 10.1108/JSBED-10-2013-0141

International Furniture Research Group (IFRG) (2018). Ethnicity and entrepreneurship in the Malaysian furniture industry - An exploratory study (Report No. 14), International Furniture Research Group, Singapore. 
Lampadarios, E. (2015). Critical Success Factors for SMEs: An Empirical Study in the UK Chemical Distribution Industry, Ph.D. Dissertation, Leeds Beckett University, Leeds, England.

Lampadarios, E. (2016). "Critical success factors for SMEs: An empirical study in the UK chemical distribution industry," International Journal of Business and Management 11(7), 67-82. DOI: 10.5539/ijbm.v11n7p67

Lampadarios, E. (2017). "An insight into entrepreneurial success factors for SMEs: The case of the UK chemical distribution industry," International Journal of Small Business and Entrepreneurship Research 5(2), 1-20.

Lampadarios, E., Kyriakidou, N., and Smith, G. J. (2017). "Towards a new framework for SMEs success: A literature review," International Journal of Business and Globalisation 18(2), 194-232. DOI: 10.1504/IJBG.2017.10001686

Lussier, R. N., and Halabí, C. E. (2010). "A three-country comparison of the business success versus failure prediction model," Journal of Small Business Management 48(3), 360-377. DOI: 10.1111/j.1540-627X.2010.00298.x

Malaysian Timber Industry Board (MTIB) (2020). Annual Report of the Malaysian Wood Industry, MTIB, Kuala Lumpur, Malaysia.

Mamat, M., and Ismail, A. (2011). "The study of Bumiputera furniture industry in Kelantan," American International Journal of Contemporary Research 1(3), 88-98.

Mazzarol, T. (2015). "SMEs engagement with e-commerce, e-business and e-marketing," Small Enterprise Research 22(1), 79-90. DOI: 10.1080/13215906.2015.1018400

McLarty, R., Pichanic, M., and Sarapova, J. (2012). "Factors influencing the performance of small to medium-sized enterprises: An empirical study in the Czech Republic," International Journal of Management 29(3), 36-47.

Minai, M. S., and Lucky, I. O. E. (2011). "Re-investigating the effect of individual determinant, external factor and firm characteristics on small firm performance during economic downturn," African Journal of Business Management 5(26), 1084610854. DOI: $10.5897 / A J B M 11.1825$

Ministry of International Trade and Industry (MITI) (2018). Status of Digital Technology Application in the Manufacturing Sector in Malaysia, MITI Press, Kuala Lumpur, Malaysia.

Noor, M. N. H. M., Kadir, R., and Muhamad, S. (2020). "Illegal logging and forest offences in Peninsular Malaysia: Perceived opportunity factors," Journal of Nusantara Studies (JONUS), 5(2), 86-102. DOI: 10.24200/jonus.vol5iss2pp86-102

Osman, N. S., Rahman, K. A. A. A., Rahman, A. R. A., and Ja'afar, M. F. Z. (2018a). "Competitive influence factors among Bumiputera furniture manufacturer," International Journal of Academic Research in Business and Social Sciences 8(7), 445-452. DOI: 10.6007/IJARBSS/v8- i7/4386

Osman, N. S., Rahman, K. A. A. A., Rahman, A. R. A., and Ja'afar, M. F. Z. (2018b). "The effect of design capability characteristic on design performance for Bumiputera furniture companies," International Journal of Business and Management 2(3), 3035. DOI: 10.26666/rmp.ijbm.2018.3.5

Osman, N. S., Rahman, K. A. A. A., Rahman, A. R. A., and Ja'afar, M. F. Z. (2019). "The challenges of Bumiputera furniture SME in design capabilities," International Journal of Business and Management 3(2), 21-25. DOI: 10.26666/rmp.ijbm.2019.2.3

Othman, M. N., Ghazali, E., and Ong, C. C. (2005). "Demographics and personal characteristics of urban Malaysian entrepreneurs: An ethnic comparison," International Journal of Entrepreneurship and Innovation Management 5(5/6), 421 440. DOI: 10.1504/IJEIM.2005.006997 
Ratnasingam, J., and Ioras, F. (2003). "The sustainability of the Asian wooden furniture industry," Holz als Roh- und Werkstoff 61, 233-237.DOI:10.1007/s00107-003-0382-9

Ratnasingam, J. (2015). The Malaysian Furniture Industry - Unravelling Its Growth and Challenges to Innovation, Universiti Putra Malaysia Press, Serdang, Selangor, Malaysia.

Ratnasingam, J. (2018). Delayed Success - Performance of Bumiputera Entrepreneurs in the Malaysian Furniture Sector, Universiti Putra Malaysia Press, Serdang, Malaysia.

Ratnasingam, J., Ioras, F., Ab Latib, H., Shukri, M., and Abdul Latib, S. (2018). "Transforming forest education to meet the changing demands for professionals," Journal of Tropical Forest Science 30(Anniversary Issue), 431-438. DOI: $10.26525 / \mathrm{jtfs} 2018.30 .5 .431438$

Ratnasingam, J., Ab Latib, H., Lee, Y. Y., Lim, C. L., and Khoo, A. (2019). "Extent of automation and readiness for industry 4.0 among Malaysian furniture manufacturers," BioResources 14(3), 7095-7110. DOI: 10.15376/biores.14.3.7095-7110

Ratnasingam, J., and Teoh, C. L. (2019). "Foreign workers in the wood industry - A boon or bane?," in: International Furniture Research Group (IFRG) (Report No. 2$\mathrm{SP})$, Singapore.

Ratnasingam, J., Khoo, A., Natkuncaran, J., Lum, C. W., Ab Latib, H., Thanasegaran, G., Lim C. L., Lee, Y. Y., Kamaruzaman, O., and Amir, M. A. (2020). "How are small and medium enterprises (SMEs) in Malaysia's furniture industry coping with the COVID-19 pandemic? Early evidence from a survey and recommendations for policymakers," BioResources 15(3), 5951-5964. DOI: 10.15376/biores.15.3.59515964

Ratnasingam, J., Ioras, F., Liat, L. C., Ayenkaren, J., Yi, L. Y., and Ab Latib, H. (2021). "Digital technology application among Malaysian value-added wood products manufacturers," BioResources 16(2), 2876-2890. DOI: 10.15376/biores.16.2.28762890

Rogoff, E. G., Lee, M.-S., and Suh, D.-C. (2004) “Who done it?” Attributions by entrepreneurs and experts of the factors that cause and impede small business success," Journal of Small Business Management 42(4), 364-376. DOI: 10.1111/j.1540- 627X.2004.00117.x

Schreier, M. (2012). Qualitative Content Analysis in Practice, Sage Publications, Thousand Oaks, CA, USA.

SME Corp. (2020). Status of SMEs in Malaysia - An Update. Small and Medium Enterprise Corporation, Small \& Medium Enterprises Corporation of Malaysia, Malaysia, Petaling Jaya, Malaysia.

Simpson, M., Padmore, J., and Newman, N. (2012). "Towards a new model of success and performance in SMEs," International Journal of Entrepreneurial Behavior and Research 18(3), 264-285. DOI: 10.1108/13552551211227675

Smith, R. L., and Valverde, P. F. (2019). "The current and future state of wood science education in the United States," Wood and Fiber Science 51(2), 1-10. DOI: 10.22382/wfs-2019-022

World Bank (2021). Aiming High - Navigating the Next Stage of Malaysia's Development, World Bank Group, Kuala Lumpur, Malaysia.

Article submitted: March 20, 2021; Peer review completed: June 13, 2021; Revised version received and accepted: June 20, 2021; Published: June 22, 2021.

DOI: 10.15376/biores.16.3.5586-5600 